University of Nebraska - Lincoln

DigitalCommons@University of Nebraska - Lincoln

1982

\title{
UTILIZATION OF THE INTACT MALE FOR RED MEAT PRODUCTION: A REVIEW
}

S. C. Seideman

United States Department of Agriculture

H. R. Cross

United States Department of Agriculture

R. R. Oltjen

United States Department of Agriculture

B. D. Schanbacher

USDA-ARS

Follow this and additional works at: https://digitalcommons.unl.edu/usdaarsfacpub

Part of the Agricultural Science Commons

Seideman, S. C.; Cross, H. R.; Oltjen, R. R.; and Schanbacher, B. D., "UTILIZATION OF THE INTACT MALE FOR RED MEAT PRODUCTION: A REVIEW" (1982). Publications from USDA-ARS / UNL Faculty. 764. https://digitalcommons.unl.edu/usdaarsfacpub/764

This Article is brought to you for free and open access by the U.S. Department of Agriculture: Agricultural Research Service, Lincoln, Nebraska at DigitalCommons@University of Nebraska - Lincoln. It has been accepted for inclusion in Publications from USDA-ARS / UNL Faculty by an authorized administrator of DigitalCommons@University of Nebraska - Lincoln. 


\title{
UTILIZATION OF THE INTACT MALE FOR RED MEAT PRODUCTION: A REVIEW
}

\author{
S. C. Seideman, H. R. Cross, R. R. Oltjen and B. D. Schanbacher \\ US Department of Agriculture, Clay Center, NE 68933
}

\begin{abstract}
Summary
Castration has long been a traditional practice in the United States. Research studies indicate that intact males grow more rapidly, utilize feed more efficiently and produce a higher-yielding carcass with less fat and more edible product. The disadvantages of the intact male include aggressive behavior (bull and boar); undesirable odors and flavors (boar and ram); lower quality grade (bull); lower meat tenderness (bull and ram) and undesirable meat color (bull and ram). Research is needed to develop antemortem and(or) postmortem handling procedures that offset the disadvantages of the intact male so that the meat and livestock industry can take advantage of their rapid growth and favorable lean production traits. This paper reviews the growth characteristics, carcass traits and consumer acceptance of meat from intact males.
\end{abstract}

(Key Words: Intact Male, Beef, Pork, Lamb, Consumer Acceptance.)

\section{Introduction}

Castration of male meat-producing animals, particularly cattle, sheep and swine, has long been a traditional practice in the United States. This practice is intended to produce an animal more acceptable to current management systems and provide a more desirable carcass for marketing. During the past four decades, a number of research studies have been conducted to assess the performance and meat characteristics of castrates vs noncastrates. In general, the results have indicated that intact males grow more rapidly, utilize feed more efficiently and produce a higher-yielding carcass (more retail product) with less fat and more red meat than castrates.

Increased production efficiency obtained through the use of intact males has often been offset by management problems, particularly with animal behavior. Meat production from intact males has encountered strong resistance from packers, in part because of the price difference between carcasses from bulls and steers. The price difference is a result of the lower USDA quality grade of bulls and the belief that beef from intact males has lower consumer acceptance at the retail level because of differences in color, texture and fat distribution. In addition, cooked meat from intact males has been labeled as less tender and, in some species, as having an undesirable flavor or odor when compared with that of castrates.

Even though castration of male domestic meat-producing animals is popular in the United States for economic and consumer acceptance reasons, most countries in Europe now utilize intact males for a large percentage of their meat supply. Brannang (1969) indicated that $53 \%$ of the slaughter cattle in Sweden are bulls.

This review describes the growth characteristics, carcass traits and consumer acceptability of meat from intact male cattle, swine and sheep carcasses. A discussion is presented to summarize the advantages and disadvantages of producing and marketing intact males.

\section{Cattle}

Growth Characteristics. Studies to quantify the differences between bulls and steers in feedlot performance generally have indicated that bulls gain more rapidly and more efficiently than steers and produce leaner carcasses (Klosterman et al., 1954; Brown et al., 1962; Rhodes, 1969; Field et al., 1971). Arthaud et al. (1977) reported that at all ages $(12,15,18$ and 24 mo of age), bulls gained faster on less feed per unit of gain and produced carcasses with lower fat percentages than steers.

Some research indicates that when cattle are reared on pasture, steers may have higher weight gains than bulls (Homb, 1958; Tylecek, 1958). Martin et al. (1978) concluded that 
because bulls fed a low protein diet gained at essentially the same rate as those fed higher protein, protein efficiency favored bulls fed the lowest protein diet. However, bulls fed the high protein diets produced carcasses with more subcutaneous fat than bulls fed the low protein diet.

Some of the most important characteristics of the mature male include redistribution of body fat and increased body musculature. The latter is associated with a positive nitrogen balance which has been ascribed to the protein anabolic effects of testicular hormones (Galbraith et al., 1978). There is little doubt that our basic understanding of the testes arose in early civilization from the practical procedure of castration.

The beneficial effect of the testis and its endocrine function on production efficiency of meat animals has been documented; however, the benefits derived from expensive androgen and estrogen replacement therapies remain controversial. On the basis of these conclusions, castration of meat-producing animals (at least males) is a questionable practice.

Many investigators have shown that synthetic estrogen implants of intact bulls increases the fatness of their carcasses (Bailey et al., 1966). This effect is in contrast to that obtained in steers. Baker and Arthaud (1972) reviewed 40 research papers on this topic and concluded that one-third of the studies showed that hormonal treatment had a negative effect on rate of gain and another one-third showed that the effect was negligible. Bailey et al. (1966) and Harte (1969) found that hormone treatment increased fat deposition in bulls but decreased fat deposition in steers.

Stilbestrol treatment tends to increase fat deposition in bulls and under certain conditions improves carcass grade (Klosterman et al., 1955; Cahill et al., 1956; Bailey et al., 1966); however, the hormone has little or no effect on tenderness of meat from bull carcasses. Wierbicki et al. (1955) and Cahill et al. (1956) reported that carcasses of treated and untreated bulls were similar in tenderness. Forrest (1975) reported that the implantation of progesterone decreased fat deposition in steers and increased fat deposition in bulls but the hormone did not affect sensory properties. Bailey et al. (1966) reported that stilbestrol implantation $(60 \mathrm{mg}$ ) decreased percentage ether extract in the longissimus muscle of steers, but increased intramuscular fat slightly in bulls. Differences in tenderness and flavor between bulls and stilbestrol-treated steers were nonsignificant.

A production problem associated with raising bulls is that of their aggressive manner and subsequent destruction of fences, feeders, etc. Some producers have reduced this problem by backgrounding calves and yearlings together on pasture before placing them in the feedlot. Once in the feedlot and until time of slaughter, they are never mixed with strange animals. Breed and seasonal changes in the weather could influence behavior but these effects have yet to be documented. In addition, research is needed to understand the hormonal system in bulls and its association with growth and aggressive behavior. Price and Tennesson (1981) investigated the influence of social interaction among bulls before slaughter on the incidence of dark-cutting muscle. They concluded that load size effects were not significant but mixing and regrouping strange bulls together significantly increased the incidence of dark-cutting muscle ( 2 vs $73 \%$ ).

Carcass Merit. Nichols et al. (1964), Bailey et al. (1966), Jacobs et al. (1977) and Landon et al. (1978) reported that steers have more marbling, more subcutaneous fat, less longissimus area, more kidney fat and a higher USDA quality grade than bulls. Brannang (1966) and Hedrick (1968) reported that dressing percentage was similar for bulls and steers. Field (1971), citing 15 references, reported that average dressing percentage and fat thickness were $59.7 \%$ and $9.3 \mathrm{~mm}$, respectively, for bulls and $59.6 \%$ and $14.3 \mathrm{~mm}$, respectively, for steers.

Ntunde et al. (1977), using Holstein-Friesian cattle fed to $7.0 \mathrm{~mm}$ fat thickness, reported that bulls required more days on feed to reach that fat thickness endpoint but yielded significantly heavier, leaner carcasses that contained a greater percentage of trimmed chuck and forequarter cuts, less trimmable fat and a higher lean to fat ratio than steers. Field (1971) cited eight references to show that bull carcasses had slightly less marbling than steer carcasses.

Bull carcasses are more mature physiologically on the basis of bone ossification and lean color than carcasses from steers of the same chronological age (Glimp et al., 1971). Sex $x$ chronological age interactions were observed by Arthaud et al, (1977) for secondary sex characteristics and physiological maturity. At 12 mo of age, differences between bulls and steers in cartilage development were negligible, but at 
older ages, bull carcasses consisiently exhibited more advanced maturity.

Kay and Houseman (1974) reported that bull carcasses contain approximately $8 \%$ more muscle and $38 \%$ less fat than steer carcasses. Field (1971) reported that bulls had an average advantage over steers of 2.6 percentage points in estimated boneless chuck, rib, loin and round. Champagne et al. (1969) found a difference of 4.8 percentage points in actual carcass cutout. Differences in percentage bone are small, but bull carcasses have much higher muscle to bone ratios than steer carcasses (Berg and Butterfield, 1968).

Jacobs et al. (1977) reported that, on a boneless basis, bull carcasses contained $58 \%$ less crude fat and $23 \%$ more crude protein than steer carcasses. Bull carcasses yielded $5.5 \%$ more boxed beef than steers, and cutting trim waste was $17 \%$ less than in steers. Bull carcasses had higher in-store retail yield and were worth approximately $15 \%$ more to the retailer than were steer carcasses. Landon et al. (1978) also reported that total retail cuts were greater for bulls than for steers.

Part of the industry resistance to young bulls is caused by difficulty of removing the hide. Bull hides are usually thicker and more difficult to remove than hides from heifers and steers. This problem increases the processing costs significantly and reduces acceptability by the packer. Another serious disadvantage to the packer is the lower USDA quality grade of the bull when compared to the steer or heifer. The United States meat industry relies heavily on USDA grades as a marketing tool. Because of variability in tenderness of young bulls, USDA has a separate classification for bulls in the quality grading system; carcasses identified as bulls are designated as "bullocks." Further research is needed to evaluate the need for a separate grading system for young bulls

Consumer Acceptance. In numerous studies reviewed by Field (1971), bull meat was slightly less tender than steer meat. In other studies, Glimp et al. (1971), Albaugh et al. (1975), Arthaud et al. (1977) and Ntunde et al. (1977) reported that bull meat had acceptable tenderness ratings, but that ratings were slightly lower than those for steer meat. In contrast to previous reports, Landon et al. (1978) observed no differences due to sex condition in WarnerBratzler shear force values. Hunsley et al. (1971) concluded that sex and chronological age may have a more adverse effect on tender- ness in bull beef than in steer beef. Field (1971) reported that, in seven of seven studies, bull beef had higher shear force values than steer beef. Hedrick et al. (1969) reported that Warner-Bratzler shear force values and sensory panel scores indicated that steaks from bulls less than 16 mo of age were comparable in tenderness to steaks from steers and heifers of similar age, whereas steaks from more mature bulls were less tender. Flavor and juiciness scores of cooked steaks were not significantly affected by sex condition. Forrest (1975) reported that rib roasts from bulls (less than 15 mo) were less tender, less juicy, less flavorful and received lower overall palatability scores than roasts from steers.

Klosterman et al. (1954) reported only slight differences in tenderness between bulls and steers slaughtered at a relatively young age. Brown et al. (1962) and Lewis et al. (1965) observed that differences in tenderness between bulls and steers slaughtered at 13 mo of age were minimal. Results given by Adams and Arthaud (1963), Wipf et al. (1964) and Field et al. (1965) suggest that an age gradient may exist in quality factors of bulls.

Linke et al. (1967) and Pelczynska (1970) found that bull muscle contained more connective tissue than cow muscle, but the differences were not high; however, Wilson et al. (1954) and Richey and Cover (1962) found no relationship between connective tissue and sex of animals. Boccard et al. (1979) investigated the influence of sex on the amount of total and soluble collagen in various beef muscles. They reported that the collagen content of muscle was higher in bulls than in steers, regardless of age, and that collagen solubility decreased markedly between 12 and 16 mo in bulls. They speculated that the increase in collagen in bulls between 8 and 12 mo of age is concomitant with sexual development and may be subject to some endocrine function in the animal. Boccard et al. (1979) also showed that the evolution of muscle collagen was not the same for Afrikaner and Friesian bulls. Thus, the collagen and age interaction may be breed related and closely linked to the onset of puberty.

Reagan et al. (1971) reported that steaks from steer carcasses were assigned significantly higher flavor scores than steaks from bull carcasses. Steaks from bulls $385 \mathrm{~d}$ of age were less tender than steaks from steers of the same age, however, this difference was not as apparent between steaks from bulls and steers that were 
$484 \mathrm{~d}$ of age. It was apparent in this study that steaks from bull carcasses were considerably more variable in palatability attributes than were those from steer carcasses.

Hedrick et al. (1969) and Arthaud et al. (1977) noted that chronological age did not seem to influence the flavor and juiciness scores of steaks from bulls. Field et al. (1966) reported that flavor and juiciness scores were not affected significantly by age of bulls when marbling was held constant, but that roasts from older bulls were generally scored lower. However, Arthaud et al. (1977) reported that chronological age significantly affected juiciness and flavor scores. Reagan et al. (1971) noted that steaks derived from bulls may acquire undesirable flavor traits between the ages of 385 and $484 \mathrm{~d}$ of age.

Hood and Allen $(1970,1971)$ reported that the aroma of cooked beef differed significantly between the sexes. However, in general, very little difference, and no meaningful trends, have been reported in flavor of meat obtained from bulls vs steers (Field, 1971).

It is often reported that meat from bulls is darker in color and coarser in texture than meat from steers (Field, 1971; Berry et al., 1972; Jeremiah, 1978; R. R. Riley, J. W. Savell, C. E. Murphey, G. C. Smith, D. M. Stiffler and H. R. Cross, unpublished data). Weninger and Steinhauf (1968) and Watson (1969) found similar myoglobin concentrations in bulls and steers. Field (1971) suggested that because of their temperament, bulls may be more easily stressed than steers and, therefore, are candidates for dark cutters. Kousgaard (1980) reported over $18 \%$ of young bulls had a $24 \mathrm{~h} \mathrm{pH}$ greater than 6.0 , and as a result had significantly darker colored lean than steers. Boccard et al. (1979) reported that the pigment content of muscle from bulls was not always higher than that of steers, but rather that differences were breeddependent.

It is obvious from the literature that meat from young bulls is tougher and more variable in tenderness and darker in color than that from steers. Differences in tenderness perhaps could be caused by myofibrillar shortening (cold shortening) or connective tissue. Perhaps some of the deficiencies could be corrected with altered antemortem and postmortem handling techniques. Preslaughter handling and feeding before slaughter could possibly influence the muscle glycogen level at death and eventually the ultimate $\mathrm{pH}$ and muscle color. Much additional research is required to understand the interaction of diet, breed and procedures on carcass traits.

Postmortem treatments might include electrical stimulation and control of the rate of temperature decline. The utilization of electrical stimulation by beef slaughteres is widespread (Savell, 1979) and it is well established that electrical stimulation improves the palatability of beef steaks (Savell et al., 1977, 1978a,b,c, 1979; McKeith et al., 1981). Furthermore, it is becoming increasingly apparent that subcutaneous fat thickness is related to beef tenderness through its effect as an insulator to reduce the rate of chilling and the related muscle fiber cold-shortening phenomenon (Smith et al., 1976; Bowling et al., 1977, 1978; Dolezal et al., 1982). If electrical stimulation could eliminate some of the variation in palatability of steaks from young bulls and(or) if some minimum subcutaneous fat thickness could assure that beef from young bulls would have "acceptable" tenderness, utilization of young bulls might become more widespread.

R. R. Riley, J. W. Savell, C. E. Murphey, G. C. Smith, D. M. Stiffler and H. R. Cross (unpublished data) investigated the effects of electrical stimulation and subcutaneous fat thickness on tenderness of the longissimus of bulls and steers. They found that electrical stimulation (ES) produced the greatest improvement in tenderness of steaks from young bulls with less than $6.5 \mathrm{~mm}$ fat thickness. They reported few differences in tenderness between bulls and steers when the fat thickness exceeded $7.62 \mathrm{~mm}$. In contrast, J. D. Crouse, S. C. Seideman and H. R. Cross (unpublished data) found no effects of ES on tenderness of bulls but significant effects on steers. Meat (steaks) from bulls was more than one sensory panel score inferior to that from steers. In the same study, $8 \mathrm{~h}$ of high temperature conditioning ( 16 C) improved the tenderness of bulls but not enough to equal that of steers. Results from the latter study suggest that variations in tenderness associated with sex condition are related to the connective tissue component while the data reported in the former study suggest' that differences in tenderness are caused by cold shortening. These differences in response to ES are not necessarily in conflict because the average fat thicknesses in the J. D. Crouse, S. C. Seideman and H. R. Cross (unpublished data) study was $8.1 \mathrm{~mm}$ for bulls and $12.1 \mathrm{~mm}$ for steers, thus the rate of temperature decline was 
likely not rapid enough in bulls to induce cold shortening.

It seems from this review that there are numerous advantages and some critical disadvantages to producing young bulls for the block beef trade. These advantages and disadvantages are summarized in table 1 . Serious problems associated with meat from young bulls include: dark cutting muscle (DFD) caused by muscle glycogen depletion before slaughter; tenderness variability; coarse muscle texture and dark appearance; lower USDA quality grade; difficult hide removal; and large carcass weights.

Research is needed to evaluate the influence of preslaughter handling and breed on the animal's reaction to stress. The DFD condition is much more widespread in young bulls than steers and heifers (Tarrant, 1980) and represents a serious consumer acceptance and shelf-life problem. In addition, if hot-processing were to become widespread, a means of detecting DFD carcasses within 2 to $3 \mathrm{~h}$ postmortem would be required.

The boxed beef and retail segment of the meat industry places price constraints on bulls with too little fat (usually less than $.6 \mathrm{~mm}$ ) and carcasses that are too large (over $375 \mathrm{~kg}$ ). The maximum acceptable carcass weight has increased gradually over the years but packer and retail resistance is still quite high to excessively heavy or underfinished carcasses. Steers may be more cost effective than bulls because they will likely reach the minimum fat endpoint sooner than bulls, thus they will be in the feedlot for less time. Carcasses from bulls may be too heavy by the time adequate fat deposition is achieved. The effect of breed and(or) breed cross on the economics of fat and muscle growth in bulls should be investigated. In addition, new markets and products should be developed for lean from large bull carcasses.

\section{Swine}

Growth Characteristics. In swine, castration has less effect on growth rate than in cattle and sheep. According to Palsson (1955), castration promotes earlier maturity in pigs than in cattle and sheep, possibly because of differences

TABLE 1. SUMMARY OF ADVANTAGES, DISADVANTAGES AND RESEARCH NEEDS FOR UTILIZING BULLS FOR RED MEAT PRODUCTION

\begin{tabular}{|c|c|c|}
\hline Variable (as compared to castrate) & $\begin{array}{l}\text { Advantages of } \\
\text { producing bulls }\end{array}$ & $\begin{array}{l}\text { Future research } \\
\text { needs }\end{array}$ \\
\hline $\begin{array}{l}\text { Growth characteristics } \\
\text { Growth rate ( } 17 \% \text { higher average daily gain) } \\
\text { Feed efficiency ( } 13 \% \text { higher) } \\
\text { Breed effects } \\
\text { Animal behavior } \\
\text { Hormonal supplementation }\end{array}$ & $\begin{array}{l}9 \\
9 \\
n / a b \\
n / a b \\
6\end{array}$ & $\begin{array}{l}\text { none } \\
\text { none } \\
\text { major } \\
\text { major } \\
\text { major }\end{array}$ \\
\hline $\begin{array}{l}\text { Carcass traits } \\
\text { Leaner carcasses ( } 35 \% \text { less fat) } \\
\text { Quality grade } \\
\text { Yield grade } \\
\text { Dressing \% (.2\% higher) } \\
\text { Marbling } \\
\text { Fat cover } \\
\text { Carcass weight } \\
\text { Hide removal } \\
\text { Stress (dark cutters) }\end{array}$ & $\begin{array}{l}8 \\
3 \\
7 \\
4 \\
3 \\
2 \\
2 \\
2 \\
2\end{array}$ & $\begin{array}{l}\text { none } \\
\text { major } \\
\text { none } \\
\text { none } \\
\text { minor } \\
\text { major } \\
\text { major } \\
\text { major } \\
\text { major }\end{array}$ \\
\hline $\begin{array}{l}\text { Consumer acceptance } \\
\text { Tenderness } \\
\text { Flavor } \\
\text { Juiciness } \\
\text { Color } \\
\text { Texture }\end{array}$ & $\begin{array}{l}3 \\
5 \\
5 \\
3 \\
3\end{array}$ & $\begin{array}{l}\text { major } \\
\text { minor } \\
\text { none } \\
\text { major } \\
\text { major }\end{array}$ \\
\hline
\end{tabular}

${ }^{a} 10=$ major advantage; 5 = no advantage; 1 = major disadvantage.

$b_{n / a}=$ not available or based on very little information. 
in physiological age at castration among the three species. Turton (1969) concluded that age and weight at castration and slaughter, breed or genotype and level of nutrition may affect boar-barrow differences in average daily gain. In general, the difference in growth rate between boars and barrows is not great. Differences in feed efficiency are also small, but tend to favor boars. Walstra and Kroeske (1968) cited 22 studies from 10 countries that dealt with feed efficiency. Boars equaled or surpassed barrows in feed efficiency in all of the studies. Siers (1975) reported that boars were $7.4 \%$ more efficient in feed conversion than barrows or gilts. Prescott and Lamming (1964) have shown that the quality of the diet, especially its protein content, may be a limiting factor in comparisons of growth rates of boars and barrows. Field (1971) reported that, in general, the difference in growth rate between boars and barrows is not as great as the difference between rams and wethers or between bulls and steers. Field (1971) reported that most research reports showed that boars gain at a faster rate than barrows. Walstra and Kroeske (1968) found that barrows will grow faster than boars when fed ad libitum but that boars will grow faster when fed restricted diets. Prescott and Lamming (1964), citing eight to 12 studies, reported that growth rate and feed efficiency were $.69 \mathrm{~kg} / \mathrm{d}$ and 1.51 , respectively, for boars and $.69 \mathrm{~kg} / \mathrm{d}$ and 1.59 , respectively, for barrows.

Carcass Merit. Carroll et al. (1963) and Kroeske (1963) reported superior leanness of boar carcasses when compared with castrates. Siers (1975) reported that gilts and boars had significantly larger loin eye areas and higher ham and loin percentages than barrows. Mean backfat measurements in $\mathbf{1 5}$ different references cited by Martin (1969) and Turton (1969) were $30 \mathrm{~mm}$ for boars and $36 \mathrm{~mm}$ for barrows at market weight. According to nine references quoted by Martin (1969), boars contain 3\% more lean and $2 \%$ more bone than barrows. Prescott and Lamming (1964), citing four to seven references, reported that boars had an average dressing percentage of $74.67 \%$, a fat thickness of $31.0 \mathrm{~mm}$ and a loin eye area of $26.7 \mathrm{~cm}^{2}$, whereas barrows averaged $76.09 \%$, $39.0 \mathrm{~mm}$ and $25.9 \mathrm{~cm}^{2}$, respectively.

Lawrie et al. (1964) found that the total nitrogen percentage was higher and moisture and fat percentage lower in muscles from boars than from barrows at $90 \mathrm{~kg}$ live weight, but that the reverse tended to be true at $130 \mathrm{~kg}$ live weight.

Walstra and Kroeske (1968) concluded that boars have (1) a more favorable feed conversion rate, (2) greater carcass length, (3) less backfat thickness at shoulder, back and loin, (4) a lower percentage of fat and a higher percentage of lean, (5) higher percentages of ham and shoulder as percentages of primal cuts and (6) lower dressing percentages.

Palatability. Shelly et al. (1970) reported that sex is not significantly related to meat tenderness in swine. However, Hiner et al. (1965) showed that the meat of barrows is more tender than that of boars. Martin et al. (1968) reported that boars ranked higher in tenderness, texture and overall preference than gilts and barrows. The effects of chronological age and physiological maturity on pork tenderness was summarized by Jeremiah (1978). An inverse relationship between the animal's age or physiological maturity and meat tenderness has been reported (Kauffman et al., 1964). Field (1971) surveyed the literature and concluded that only limited research has been done to contrast the tenderness of meat obtained from boars and barrows and that this research is contradictory (Martin et al,, 1968). Field (1971) also concluded that most researchers have considered tenderness in boar meat of minor consequence and have concentrated on differences in odor and flavor of the cooked meat.

Sex odor in boars has been reviewed by Walstra and Kroeske (1968), and Martin (1969). Patterson (1968) reported that several sex taints have been encountered but concluded that the compound primarily responsible for boar odor is $5 \alpha$-androst-16-ene-3-one $(5 \alpha$ androstenone), which has been isolated from the fat of boars but not from barrows and gilts. The conclusion that the male sex hormones are the precursors of these compounds is in general agreement with the pathways of androstenal biosynthesis presented by Sink (1967).

The unpleasant musk-smell of 16-unsaturated steroids was first identified in testicular tissue from boars (Prelog and Ruzicka, 1944) and these steroids were found in high concentrations in adipose tissue (Patterson, 1968; Berry and Sink, 1971; Fuchs, 1971; Andresen, 1975a,b; Malmfors and Andresen, 1975). The pheromone, $5 \alpha$-androstenone, which is believed most closely associated with boar taint, seems to be produced in the testes (Gower and Ahmad, 1967; Ahmad and Gower, 1968). The steroid is secreted in 
response to gonadotropic stimulation (Andresen, 1975a,b; Malmfors et al., 1978) into the systemic circulation via the spermatic vein (Gower et al., 1970; Saat et al., 1972). Thus, a positive relationship exists between the secretion of $5 \alpha$-androstenone and testosterone. Testosterone may be converted systemically to $5 \alpha$-androstenone as well as induce the production of other odors that may make carcasses unacceptable.

Plimpton et al. (1971) reported that boar odor was significantly correlated with increasing age and longissimus muscle area but not with rate of gain or ether extract of the longissimus muscle. Craig et al. (1962) reported that sex odors in swine were water-soluble, ether extractable and associated with fatty tissue. Lundstrom et al. (1980) reported that neither boar taint intensity nor $5 \alpha$-androstenone, skatole or indole varied with breed. The results did show, however, that 36,33 and $7 \%$ of the variation in boar taint could be explained by a combination of $5 \alpha$-androstenone and skatole, suggesting that other components are present which can account for the other $50 \%$ of the variation (Lundstrom et al., 1980).

Martin (1969) considered the stage of maturity to be an extremely important factor in boar odor. He stated that the incidence of boar odor is high among mature boars and is virtually nil among boars slaughtered at $20 \mathrm{~kg}$ live weight or less. Wismer-Pedersen et al. (1969) reported that odor was not related to age in 1,907 boars slaughtered after use in boar service stations; however, it should be noted that even the youngest of the boars were sexually mature. Breed may influence age/ weight relationships and the time when boar odor becomes readily detectable. Teague et al. (1964) found that fast-gaining, late-maturing boars slaughtered at light weights did not present a serious odor problem. Jonsson and Wismer-Pedersen (1974) observed no significant differences in sex odor between Danish Landrace swine in weight classes from 60 to $90 \mathrm{~kg}$.

Wismer-Pedersen (1968) was uncertain whether age at puberty had any relation to occurrence of boar odor. Staun (as cited by Wismer-Pedersen, 1968) observed sex odor in late-maturing Danish Landrace boars slaughtered at weights as low as $55 \mathrm{~kg}$.

The genetic control of sex odor in boar meat is of obvious importance, as the presence of "boar taint" in cooked meat from intact male pigs is the reason most often cited for not producing boars for slaughter. Jonsson and Wismer-Pedersen (1974) estimated the heritability of sex odor in boars of the Danish Landrace breed to be $.54 \pm .32$. A heritability of this magnitude would indicate that fairly rapid progress could be made by selection in reducing sex odor. However, if one is to select against boar odor ( $5 \alpha$-androstenone), it is important to know when correlated changes may occur in other traits such as libido, fertility, growth and fat thickness. Jonsson and Wismer-Pedersen (1974) reported no biologically significant antagonistic effects of sex odor intensity on boars' libido or on the average size of the litters borne by their mates. Andresen and Bakke (1975) and Andresen (1976) found significantly lower levels of $5 \alpha$-androstenone in the systemic plasma of boars selected for a high rate of gain and low backfat than in the plasma of boars selected for a low rate of gain and high backfat. There was no significant difference between lines in the concentration of $5 \alpha$-androstenone in the fat, but concentration was higher in the line selected for low gain and high backfat. Malmfors et al. (1978) reported no significant correlation between boar odor and carcass proportions or carcass leanness; they found a slight indication that higher growth rate was associated with lower intensity of boar taint. In a small data set, Alsing et al. (1977) found a somewhat higher growth rate in boars selected for high concentrations of $5 \alpha$-androstenone than in boars selected for low concentrations.

Castration of male pigs a few days or weeks of age to prevent development of objectionable male odors and flavors in pork is a common practice. This practice carries with it a compromise in the form of reduced rate of weight gain and efficiency of feed utilization and increased carcass fat. A substantial improvement in overall swine production economy and biological efficiency could result from the marketing of intact male pigs void of boar taint.

From this review, it can be concluded that the advantages of producing boars for red meat production are not as great as those shown for rams or bulls. The growth rate and feed efficiency of boars do offer slight advantages (table 2 ); however, these growth characteristics are likely confounded with breed effects and plane of nutrition. Boars appear to offer many advantages in carcass merit (table 2). The magnitude of these differences in carcass merit between boars and barrows, when put on a national average may not only increase the pork 
supply, but may also offer a natural method of reducing the fat content of meat. Palatability characteristics of boars (table 2), except odor and flavor, are generally similar to those of barrows. Boar odor appears to be the major problem associated with their acceptance in the marketplace. There seems to be a difference in the development of boar odor between breeds. Late maturing breeds do not seem to have the incidence of boar odor at the same slaughter weight as the early-maturing breeds.

In summary, advantages of boars in growth characteristics and carcass merit are not as large as those of bulls and rams, but may be worthy of consideration nonetheless. Growth characteristics and carcass merit of boars possibly could be improved; however, before extensive research in the growth and carcass areas is conducted, the problem of boar odor should be investigated further.

\section{Sheep}

Growth Characteristics. Ram lambs grow more rapidly, utilize feed more efficiently and yield leaner carcasses than do wethers (Walker,
1950; McClaughterty et al., 1959; Wilson et al., 1970, 1972; Glimp, 1971; Schanbacher and Crouse, 1980). The superiority of ram lambs has been attributed to testicular hormones and testosterone, in particular (Schanbacher and Ford, 1976; Schanbacher et al., 1980). Field (1971) cited 13 references in which rams had an average daily gain of $.23 \mathrm{~kg}$ and wethers had an average daily gain of $.20 \mathrm{~kg}$.

Bradford and Spurlock (1964) concluded that ram lambs weighed $5 \%$ more than wethers at weaning and 15 and $23 \%$ more as yearlings on high and low planes of nutrition, respectively. Purchas (1978) concluded that ram lambs may not show clear growth advantages over wethers during postweaning periods on pasture and that they are likely to yield less carcass weight per unit of live weight; however, they do produce carcasses with lower fat percentages at all weights. Various researchers (Garrigus et al., 1962; Ray and Mandigo, 1963; Zinn et al., 1963; Menzies, 1965) have reported that ram lambs are superior to wether and ewe lambs in rate of feedlot gain and carcass weight per day of age. According to Deweese et al. (1969) and Jacobs (1970), rams are 12 to $15 \%$ more

TABLE 2. SUMMARY OF ADVANTAGES, DISADVANTAGES AND RESEARCH NEEDS FOR UTILIZING BOARS FOR RED MEAT PRODUCTION

\begin{tabular}{|c|c|c|}
\hline Variable (as compared to castrate) & $\begin{array}{l}\text { Advantages of } \\
\text { producing boars }\end{array}$ & $\begin{array}{l}\text { Future research } \\
\text { needs }\end{array}$ \\
\hline $\begin{array}{l}\text { Growth characteristics } \\
\text { Growth rate (.66\% higher) } \\
\text { Feed efficiency ( } 5.3 \% \text { higher) } \\
\text { Breed effects } \\
\text { Animal behavior } \\
\text { Type of feed } \\
\text { Hormonal supplementation }\end{array}$ & $\begin{array}{l}6 \\
6 \\
\mathrm{n} / \mathrm{a}^{b} \\
3 \\
5 \\
6\end{array}$ & $\begin{array}{l}\text { minor } \\
\text { minor } \\
\text { major } \\
\text { major } \\
\text { minor } \\
\text { major }\end{array}$ \\
\hline $\begin{array}{l}\text { Carcass merit } \\
\text { Leaner carcasses } \\
\text { Larger loineye area }(3.24 \%) \\
\text { Less backfat }(20.5 \%) \\
\text { Lower dressing } \%(1.87 \%)\end{array}$ & $\begin{array}{l}7 \\
6 \\
7 \\
4\end{array}$ & $\begin{array}{l}\text { none } \\
\text { none } \\
\text { none } \\
\text { minor }\end{array}$ \\
\hline $\begin{array}{l}\text { Palatability } \\
\text { Tenderness } \\
\text { Flavor and odor } \\
\text { Causes } \\
\text { Breed effects } \\
\text { Maturity } \\
\text { Type of feed } \\
\text { Juiciness }\end{array}$ & $\begin{array}{l}5 \\
1 \\
\mathrm{n} / \mathrm{a}^{b} \\
\mathrm{n} / \mathrm{a}^{b} \\
\mathrm{n} / \mathbf{a}^{b} \\
\mathrm{n} / \mathrm{a}^{b} \\
5\end{array}$ & $\begin{array}{l}\text { minor } \\
\text { major } \\
\text { major } \\
\text { major } \\
\text { major } \\
\text { major } \\
\text { none }\end{array}$ \\
\hline
\end{tabular}

\footnotetext{
${ }^{2} 10=$ major advantage; 5 = no advantage; 1 = major disadvantage.

$b_{n / a}=$ not available or based on very little information.
} 
efficient in converting feed into live weight gain than wethers, and Orskov et al. (1974) found that rams were $13 \%$ more efficient than ewes.

Carcass Traits. Lamb carcasses presently are sold in the United States on a quality grade basis, which is of great economic importance to producers, packers and retailers of lamb. Studies by Bradford and Spurlock (1964), Pattie et al. (1964), Botkin et al. (1967), Hudson et al. (1968), Kemp et al. (1970) and Schanbacher and Crouse (1980) have indicated only minor differences in USDA quality grades between ram and wether carcasses; however, these minor differences tend to favor wether carcasses. USDA yield grades generally favor rams over wethers. Several researchers (Bradford and Spurlock, 1964; Carpenter et al., 1964; Field et al., 1967) agree that rams have lower dressing percentages, are leaner and have higher yields of retail cuts than wethers. Field (1971), citing 13 references, reported that rams had an average dressing percentage of $49.6 \%$ and a fat thickness of $5.2 \mathrm{~mm}$, whereas wethers had an average dressing percentage of $51.3 \%$ and a fat thickness of $6.9 \mathrm{~mm}$.

Field (1971) cited 11 references to indicate that the estimated retail yield favored rams over wethers. Shelton and Carpenter (1972) found that not only is the amount of fat less in rams than in wethers or ewes, but the rate of fat deposition is also much lower at heavy weights (64 $\mathrm{kg}$ live weight) in rams. Kemp et al. (1972) observed that fat measurements were greater for wethers than for rams in light weight groups and that these differences between sexes became greater as weight increased. Crouse et al. (1981) found ram lamb carcasses to be significantly leaner than ewe or wether lamb carcasses.

Because androgens generally are considered responsible for bone development, it would be logical to expect rams to have heavier and larger bones than wethers. Field et al. (1967) found 18.9 and $16.5 \%$ bone in rams and wethers, respectively, whereas Kemp et al. (1970) reported 17.7 and $16.7 \%$ bone in rams and wethers, respectively.

The distribution of carcass lean is different in rams and wethers, which may be attributed to adrogens. Bradford and Spurlock (1964), Prescott and Lamming (1964), Jacobs (1970) and Kemp et al. (1970) reported that ram lambs have a higher proportion of neck and shoulder cuts than wethers. The increased proportion of neck and shoulder cuts most likely is caused by stimulation of muscle growth in these areas by testicular androgens. Carcasses with prominent neck and shoulder muscles are described as "bucky," and a lower USDA quality grade is assigned to such carcasses. Muscles from rams have the largest muscle fibers, wethers intermediate-sized muscle fibers and ewes the smallest fibers (Hammond, 1932).

Soft, oily and sometimes yellow fat is often observed in carcasses from ram lambs. This condition may be seasonal and the cause has been difficult to document (Crouse et al., 1978, 1981). The meat industry objects to this condition and the carcass is usually discounted.

The pelt of ram carcasses is more difficult to remove when compared to wethers. This increases the processing costs associated with slaughtering of rams.

Palatability. Hunt et al. (1938) found that meat from rams was less tender than meat from wethers on the basis of shear force measurements, but did not find any differences in palatability between the meat of rams and wethers of the same chronological age. Bradford and Spurlock (1964) reported that meat from ram and wether lambs did not vary in eating quality; however, Field et al. (1966) reported that meat from wethers was more desirable to sensory panelists than meat from rams. Although meat from rams was considered acceptable. Field et al. (1971) citing five references, reported that shear force values for rams and wethers were 3.39 and $3.05 \mathrm{~kg}$, respectively.

In a review of the literature, Field (1971) concluded that only minor differences existed between rams and wethers in juiciness and flavor and that no trends were obvious. Sensory panel scres indicated that meat from rams was slightly less tender than meat from wethers (Field, 1971).

Age or weight does not have a consistent effect on tenderness. Some researchers reported an inverse relationship between age and cooked meat tenderness (Batcher et al., 1962; Carpenter and King, 1965; Woodhams et al., 1966; Smith and Carpenter, 1970; Smith et al., 1970; Corbett et al., 1973 ; Cross et al., 1973 ; Campion et al., 1976) while others found an increase in tenderness with age (Paul et al., 1964; Jacobs et al., 1972; Kemp et al., 1972, 1976; Field et al., 1978). Kemp et al. (1972) also observed a sex $\times$ slaughter weight interaction for tenderness. Ram meat increased in tenderness with increased weight at a faster rate than wether meat, but meat from wethers was still more 
tender than meat from rams. Riley et al. (1981) reported that ES of ram lamb carcasses improved tenderness and color, but not equivalent to meat from unstimulated wether carcasses. Variability of results among experiments may be attributed to differences in ages and breeds of animals, degree of physiological maturity, cold shortening and rates of temperature decline.

For lamb meat to be desirable to the average U.S. consumer, it must have acceptable palatability and be devoid of mutton flavor or aroma. Batcher et al. (1969) and Jacobs (1970) reported that differences between meat from rams and wethers in juiciness and flavor were small and that no trends were apparent. According to Rhodes (1969), there is no evidence that the meat from ram lambs differs in quality in any way from meat from wether lambs. Lack of variation in flavor between sexes was observed by Batcher et al. (1969) and Jacobs (1970) when meat from 10- and 15-mo-old rams and wethers was studied. Batcher et al. (1969) observed that the differences in flavor were attributable to the age and sex of the lamb when the broth from samples of lamb and yearling mutton meat was served to panel members in triangle tests. Misock et al. (1976) observed that flavor and aroma scores of meat from heavy weight (29.3 to $41.3 \mathrm{~kg}$ carcass weights) market lambs were inferior to flavor and aroma scores for meat from lighter weight wethers. Misock et al. (1976) also observed an "ammonia" or "staggy" odor in carcasses of heavy ram lambs. This odor was particularly noticeable in the two older (183 vs 237 and 295 d) and heavier (carcass weights of $29.3 \mathrm{vs}$ 39.0 and $43.1 \mathrm{~kg}$ ) groups of rams. The ram odor in the study by Misock et al. (1976) was different from the mutton odor identified by Wong et al. (1975). Very intense flavor and aroma of meat from heavy weight market ram lambs were reported by Crouse et al. (1978, 1981). Purchas et al. (1979) observed that palatability scores of meat from wether carcasses decreased to a greater extent with increasing weight than did scores of meat from ram lambs.

Tichenor (1969) and Jacobs (1970) reported that the fat of rams contained less stearic and more linoleic and linolenic acids than compar-

TABLE 3. SUMMARY OF ADVANTAGES, DISADVANTAGES AND RESEARCH NEEDS FOR UTILIZING RAMS FOR RED MEAT PRODUCTION

\begin{tabular}{|c|c|c|}
\hline Variable (as compared to castrate) & $\begin{array}{l}\text { Advantages of } \\
\text { producing rams }^{\mathrm{a}}\end{array}$ & $\begin{array}{l}\text { Future research } \\
\text { needs }\end{array}$ \\
\hline $\begin{array}{l}\text { Growth characteristics } \\
\text { Growth rate (15\% higher) } \\
\text { Feed efficiency } \\
\text { Breed effects } \\
\text { Feedlot behavior } \\
\text { Type of feed } \\
\text { Hormonal supplementation }\end{array}$ & $\begin{array}{l}9 \\
8 \\
n / a^{b} \\
n / a b \\
n / a b \\
n / a b\end{array}$ & $\begin{array}{l}\text { minor } \\
\text { minor } \\
\text { major } \\
\text { major } \\
\text { major } \\
\text { minor }\end{array}$ \\
\hline $\begin{array}{l}\text { Carcass merit } \\
\text { Leaner carcasses ( } 3.3 \% \text { leaner) } \\
\text { Quality grade } \\
\text { Yield grade } \\
\text { Dressing } \% \text { ( } 3.3 \% \text { lower) } \\
\text { Pelt removal } \\
\text { Soft, oily and yellow fat }\end{array}$ & $\begin{array}{l}8 \\
3 \\
8 \\
3 \\
1 \\
3\end{array}$ & $\begin{array}{l}\text { minor } \\
\text { major } \\
\text { minor } \\
\text { major } \\
\text { major } \\
\text { major }\end{array}$ \\
\hline $\begin{array}{l}\text { Palatability and retail appearance } \\
\text { Breed/age effects } \\
\text { Flavor and aroma } \\
\text { Tenderness } \\
\text { Juiciness } \\
\text { Color and texture } \\
\text { Restructuring }\end{array}$ & $\begin{array}{l}n / a^{b} \\
3 \\
4 \\
5 \\
n / a b \\
n / a b\end{array}$ & $\begin{array}{l}\text { major } \\
\text { major } \\
\text { minor } \\
\text { none } \\
\text { minor } \\
\text { major }\end{array}$ \\
\hline
\end{tabular}

\footnotetext{
$a_{10}=$ major advantage; 5 = no advantage; $1=$ major disadvantage.

$b_{n / 2}=$ not available or based on very little information.
} 
able fat of wethers. Total unsaturated fatty acids were higher in rams than wethers. Flavor differences were not highly correlated with these changes, but the fatty acid changes may have been responsible for the softer fat on ram lamb carcasses.

From this review, it is obvious that ram lambs are superior to wether lambs in rate of gain and feed efficiency. Although values may vary between studies, they show considerable advantage to the use of ram lambs for red meat production (table 3 ).

A major problem facing the lamb industry is the underutilization of some lamb primal cuts and the small size of loin and rib chops. Most of the economics involved in lamb marketing orients around the leg. In order to reduce the cost per pound for the leg, producers must merchandise more desirable items from the less desirable carcass cuts. Further processing of undesirable cuts (flank, breast, shanks, etc.) can be achieved through restructuring of lamb meat. Flaked and formed or sectioned and formed cuts permit the packer to form the less desirable, smaller cuts of meat into a desirablesized steak that has excellent palatability characteristics and can be merchandized at a reasonable price.

The major disadvantages connected with the ram as compared to the wether carcass are price discounts because of lower quality grade, heavy weights, soft, oily and yellow fat, more difficult pelt removal, lower dressing percentage more intense flavor and undesirable aroma. Most of these problems are researchable and there is a high probability that improvements can be achieved. The obvious advantages of the ram lamb would seem to justify additional research effort.

\section{Literature Cited}

Adams, C. H. and V. H. Arthaud. 1963. Influence of sex and age differences on tenderness of beef. $J$. Anim. Sci. 22:1112 (Abstr.).

Ahmad, N. and D. B. Gower. 1968. The biosynthesis of some androst-16-ones from $C_{21}$ and $C_{19}$ steroids in boar testicular and adrenal tissue. Biochem. J. 108:223.

Albaugh, A., F. D. Carroll, K. W. Ellis and R. Albaugh. 1975. Comparison of carcasses and meat from steers, short scortum bulls and intact bulls. J. Anim. Sci. $41: 1627$.

Alsing, W., R. Claus, F. F. Pirchner and H. Willeke. 1977. Selektion experiment auf Ebergerich. Paper presented at the Annu. Meet. of the European Assoc. Anim. Prod., at the Commission on Animal Genetics, Brussels.
Andresen, $\emptyset$. 1975a. 5 $\alpha$-adrostenone in peripheral plasma of pigs, diurnal variation in boars, effects of intravenous hCG administration and castration. Acta Endocrinol, (Kbh.) 78:385.

Andresen, 0 . 1975b. A radioimmunoassay for $5 \alpha$ androst-16-en-3-one in porcine adipose tissue. Acta Endocrinol. (Kbh.) 79:619.

Andresen, $\emptyset$. 1976. Concentrations of fat and plasma $5 \alpha$-androstenone and plasma testosterone in boars selected for rate of body weight gain and thickness of backfat during growth, sexual maturation and after mating. J. Reprod. Fertil. 48: 51 .

Andresen, $\emptyset$. and H. Bakke. 1975. $5 \alpha$-androstenone in fat from boars selected for rate of gain and thickness of backfat, and from boars used in artificial insemination service. Acta Vet. Scand. 16:492.

Arthaud, V. H., R. W. Mandigo, R. M. Koch and A. W. Kotula. 1977. Carcass composition, quality, and palatability attributes of bulls and steers fed different energy levels and killed at four ages. J. Anim. Sci. 44:53.

Bailey, C. M., C. L. Probert, P. Richardson, V. R. Bohman and J. Chancerelle. 1966. Quality factors of the longissimus dorsi of young bulls and steers. J. Anim. Sci. 25:504.

Baker, F. H. and V. H. Arthaud. 1972. Use of hormones or hormone active agents in production of slaughter bulls. J. Anim. Sci. 35:752.

Batcher, O. M., A. W. Brant and M. S. Kunze. 1969. Sensory evaluation of lamb and yearling mutton flavors. J. Food Sci. 34:272.

Batcher, O. M., E. H. Dawson, M. R. Pointer and G. L. Gilpin. 1962. Quality of raw and cooked lamb meat as related to fatness and age of animal. Food Technol. 16:102.

Berg, R. T. and R. M. Butterfield. 1968. Growth patterns of bovine muscle fat and bone. J. Anim. Sci. 27:611.

Berry, K. E. and J. D. Sink. 1971. Isolation and identification of $3 \alpha$-hydroxy-5 $\alpha$-androst-16-ene and $5 \alpha$-androst-16-en-3-one from porcine adipose tissue. J. Endocrinol. 51:223.

Berry, B. W., G. C. Smith and Z. L. Carpenter. 1972. Influence of certain physiological maturity indicators on beef tenderness. Beef Cattle Res. in Texas PR-3131. p 27.

Boccard, R., R. T. Naude, D. E. Cronje, M. C. Smit, H. J. Venter and E. J. Rossouw. 1979. The influence of age, sex and breed of cattle on their muscle characteristics. Meat Sci. 3:280.

Botkin, M. P., C. O. Schoonover and R. A. Field. 1967. Relationship between live and carcass traits of lambs. Wyoming Agr. Exp. Sta. Res. J. 6.

Bowling, R. A., J. K. Riggs, G. C. Smith, Z. L. Carpenter and O. D. Butler. 1978. Production, carcass and palatability characteristics of steers produced by different management systems. J. Anim. Sci. 46: 333 .

Bowling, R. A., G. C. Smith, Z. L. Carpenter, T. R. Dutson and W. M. Oliver. 1977. Comparison of forage-finished and grain-finished beef carcasses. J. Anim. Sci. 45:209.

Bradford, G. E. and G. M. Spurlock. 1964. Effects of castrating lambs on growth and body composition. J. Anim. Prod. 6:291. 
Brannang, E. 1966. The effect of castration and age of castration on the growth rate, feed conversion and carcass traits of Swedish Red and White cattle. LantbrukshogskolansAnnaler 32:329.

Brannang, E. 1969. The raising of bulls for beef in Sweden. In: D. N. Rhodes (Ed.) Meat Production from Entire Male Animals. pp 173-178. J and A Churchill Ltd., London.

Brown, C. J., J. D. Bartree and P. K. Lewis, Jr. 1962. Relationships among performance records, carcass cut out data and eating quality of bulls and steers. Arkansas Agr. Exp. Sta. Bull. 655.

Cahill, V. R., L. E. Kunkle, E. W. Klosterman, F. E. Deatherage and E. Wierbicki. 1956. Effect of Diethylstilbestrol implantation on carcass composition and the weight of certain endocrine glands of steers and bulls. J. Anim. Sci. 15:701.

Campion, D. R., R. A. Field, M. L. Riley and G. M. Smith. 1976. Effect of weight on carcass merit of very heavy market ram lambs. J. Anim. Sci. 43:1218.

Carpenter, Z. L. and G. T. King. 1965. Tenderness of lamb rib chops. Food Technol. 19:1706.

Carpenter, Z. L., G. T. King, F. A. Orts and N. L. Cunningham. 1964. Factors influencing retail carcass value of lambs. J. Anim. Sci. 23:741.

Carroll, M. A., F. Hill and P. B. O'Donovan. 1963. Some effects of castration on pig carcass of pork and bacon weights. Irish J. Agr. Res. 2:177.

Champagne, J. R., J. W. Carpenter, J. F. Hentges, Jr., A. Z. Palmer and M. Koger. 1969. Feedlot performance and carcass characteristics of young bulls and steers castrated at four ages. J. Anim. Sci. 29:887.

Corbett, J. L., E. P. Furnival, W. H. Southcott, R. J Park and $W$. R. Shorthose. 1973. Induced cryptorchidism in lambs. Effects on growth rate, carcass and meat characteristics. Anim. Prod. $16: 157$.

Craig, H. B., A. M. Pearson and N. B. Webb. 1962. Fractionation of the component(s) responsible for sex odor/flavor in pork. J. Food Sci. 27:29.

Cross, H. R., Z. L. Carpenter and G. C. Smith. 1973. Effects of intramuscular collagen and elastin upon bovine muscle tenderness. J. Food Sci. 38:998.

Crouse, J. D., J. R. Busboom, R. A. Field and C. L. Ferrell. 1981. The effects of breed, diet, sex, location and slaughter weight on lamb growth, carcass composition and meat flavor. J. Anim. Sci. 53:376.

Crouse, J. D., R. A. Field, J. L. Chant, Jr., C. L. Ferrell, G. M. Smith and V. L. Harrison. 1978. Effect of dietary energy intake on carcass composition and palatability of different weight carcasses from ewe and ram lambs. J. Anim. Sci. 47:1207.

Deweese, W. P., H. A. Glimp, J. D. Kemp and D. G. Ely. 1969. Performance and carcass characteristics of rams and wethers slaughtered at different weights. Kentucky Agr. Exp. Sta. Prog. Rep. 181.

Dolezal, H. G., G. C. Smith, J. W. Savell and Z. L. Carpenter. 1982. Comparison of subcutaneous fat thickness, marbling and quality grade for predicting palatability of beef. J. Food Sci. (In press).
Field, R. A. 1971. Effect of castration on meat quality and quantity. J. Anim. Sci. 32:849.

Field, R. A., G. E. Nelms and C. D. Schoonover. 1966. Effects of age, marbling and sex on palatability of beef. J. Anim. Sci. 25:360.

Field, R. A., M. L. Riley and M. P. Botkin. 1967. Effect of sex and ram weight on composition of lambs. Proc. Western Sec. Amer. Soc. Anim. Sci. $18: 45$.

Field, R. A., M. L. Riley and Y. O. Chang. 1971. Free amino acid changes in different aged bovine muscles and their relationship to shear values. J. Food Sci. 36:611.

Field, R. A., C. O. Schoonover and G. E. Nelms. 1965. Effect of age, marbling and sex on palatability of beef. J. Anim. Sci. 24:862 (Abstr.).

Field, R. A., J. C. Williams, C. L. Ferrell, J. D. Crouse and J. E. Kunsman. 1978. Dietary alteration of palatability and fatty acids in meat from light and heavy weight ram lambs. J. Anim. Sci 47:858.

Forrest, R. J. 1975. Effects of castration, sire and hormone treatments on the quality of rib roasts from Holstein-Friesan males. Can. J. Anim. Sci. 55:287.

Fuchs, G. 1971. The correlation between the $5 \alpha-$ androst-16-ene-3-one content and the sex odour intensity in boar fat. Swedish J. Agr. Res. 1:233.

Galbraith, H., D. G. Dempster and T. B. Miller. 1978. A note on the effect of castration on the growth performance and concentrations of some blood metabolites and hormones in British Friesian male cattle. Anim. Prod. 26:339.

Garrigus, U. S., R. J. Vatthauer, E. E. Hatfield, B. B. Doane, J. H. Sohalouski and W. R. Usborne. 1962. Some effect of sex on rate of gain and carcass quality of young lambs. Proc. Western Sec. Amer. Soc. Anim. Sci. 13:39.

Glimp, H. A. 1971. Effects of sex alteration, breed, type of rearing and creep feeding on lamb growth. J. Anim. Sci. 32:859.

Glimp, H. A., M. E. Dikeman, H. J. Tuma, K. E. Gregory and L. V. Cundiff. 1971. Effect of sex condition on growth and carcass traits of male Hereford and Angus cattle. J. Anim. Sci. 33:1242.

Gower, D. B. and N. Ahmad, 1967. Studies on the biosynthesis of 16-dehydro steroids. The metabolism of $\left(4^{14} \mathrm{C}\right)$-pregnenolone by boar adrenal and testis tissue in vitro. Biochem. J. 104: 550.

Gower, D. B., F. A. Harrison and R. B. Heap. 1970. The identification of $\mathrm{C}_{19}$-16-unsaturated steroids and estimation of 17-oxosteroids in boar spermatic vein plasma and urine. J. Endocrinol. 47:357.

Hammond, J. 1932. Growth and Development of Mutton Qualities in the Sheep. Biological Monographs and Manuals. Oliver and Boyd, London.

Harte, F. J. 1969. Six years of bull beef production research in Ireland. In: D. N. Rhodes (Ed.) Meat Production from Entire Male Animals. pp 153172. J. and A Churchill Ltd., London.

Hedrick, H. B. 1968. Bovine growth and composition. Univ. of Missouri Agr. Exp. Sta. Bull. 928.

Hedrick, H. B., G. B. Thompson and G. F. Krause 1969. Comparison of feedlot performance and 
carcass characteristics of half-sib bulls, steers and heifers. J. Anim. Sci. 29:687.

Hiner, R. H., O. G. Hankins, H. S. Sloane, C. R. Fellers and E. E. Anderson. 1965. Palatability and quality of pork as influenced by breed and fatness. J. Food Sci. 30:550.

Homb, T. 1958. Sammenligning av osker og kastrater i kjøttproduksjonen [Bulls versus steers in beef production]. Beretn. ForFors $\phi k$. Norg. LandbrHøgsk., No. 87:70.

Hood, R. L. and E. Allen. 1970. Sex and postmortem aging effects on bovine lipids. J. Anim. Sci. 31:184 (Abstr.).

Hood, R. L, and E. Allen. 1971. Influence of sex and postmortem aging on intramuscular and subcutaneous bovine lipids. J. Food Sci. 36:786.

Hudson, L. W., H. A. Glimp, P. G. Woolfolk, J. D. Kemp and C. M. Reese. 1968. Effect of induced cryptorchidism at different weights on performance and carcass traits of lambs. J. Anim. Sci. $27: 45$.

Hunsley, R. E., R. L. Vetter, E. A. Kline and W. Burroughs. 1971. Effects of age and sex on quality, tenderness and collagen content of bovine longissimus muscle. J. Anim. Sci. 33:933.

Hunt, W. E., D. Meade and B. E. Carmichael. 1938. Effect of castration of lambs on their development and quality of meat. Maryland Agr. Exp. Sta. Bull. 417:259.

Jacobs, J. A. 1970. The effects of sex, weight and stress on carcass composition, fatty acid variability and organoleptic evaluation of lamb. Ph.D. Dissertation. Univ. of Wyoming, Laramie.

Jacobs, J. A., R. A. Field, M. P. Botkin, M. L. Riley and G. P. Roehrkasse. 1972. Effects of weight and castration on lamb carcass composition and quality. J. Anim. Sci, 35:926.

Jacobs, J. A., J. C. Miller, E. A. Sauter, A. D. Herves, A. A. Araji, T. L. Gregory and C. E. Hurst. 1977. Bulls versus steers. II. Palatability and retail acceptance. J. Anim. Sci. 46:699.

Jeremiah, L. E. 1978. A review of factors affecting meat quality. Tech. Bull. 1, Research Branch, Agriculture Canada.

Jonsson, P. and J. Wismer-Pedersen. 1974. Genetics of sex odour in boars. Livestock Prod. Sci, 1:53.

Kauffman, R. G., Z. L. Carpenter, R. W. Bray and W. G. Hockstra. 1964. Interrelations of tenderness, chronological age, and connective tissue fractions of porcine musculature. J. Agr. Food Chem. 12:504.

Kay, $M$. and R. Houseman. 1974. The influence of sex on meat production. In: D.J.A. Cole and R. A. Lawrie (Ed.) Proc, of the 21st Easter School in Agr. Sci. pp 85-108. Butterworth, London.

Kemp, J. D., J. D. Crouse, W. Deweese and W. G. Moody. 1970. Effect of slaughter weight and castration on carcass characteristics of lambs. J. Anim. Sci. 30:348.

Kemp, J. D., A. E. Johnson, D. F. Stewart, D. G. Ely and J. D. Fox. 1976. Effect of dietary protein, slaughter weight and sex on carcass composition, organoleptic properties and cooking losses of lamb. J. Anim. Sci, 42:575.

Kemp, J. D., J. M. Shelly, D. G. Ely and W. G. Moody. 1972. Effects of castration and slaughter weight on fatness, cooking losses and palatability of lamb. J. Anim. Sci. 34:560.

Klosterman, E. W., V. R. Cahill, L. E. Kunkle and A. L. Moxon. 1955. The subcutaneous implantation of stilbestrol in fattening bulls and steers. J. Anim. Sci. 14:1050.

Klosterman, E. W., L. E. Kunkle, P. Gerlaugh and V. R. Cahill. 1954. The effect of age of castration upon rate and economy of gain and carcass quality of beef calves. J. Anim. Sci. 13:817.

Kousgaard, K. 1980. Development of special feeds for young bulls kept in overnight lairages. Presented at ECC Seminar on "The Problem of Dark Curting in Beef," CEC, Brussels, October 7-8.

Kroeske, D. 1963. The castration of male piglings. A harmful custom or a necessary evil? Veeteelt-en Zuivelberichten 6:254.

Landon, M. E., H. B. Hedrick and G. B. Thompson. 1978. Live animal performance and carcass characteristics of beef bullocks and steers. J. Anim. Sci. 47:151.

Lawrie, R. A., R. W. Pomeroy and A. Cuthbertson. 1964. Studies on the muscles of meat animals. 6 . Comparative composition of various muscles in boars of two weight groups in relation to hogs. J. Agr. Sci. (Camb.) 63:385.

Lewis, P. K., Jr., C. J. Brown and M. L. Heck. 1965. Effects of preslaughter treatment and castration on certain organoleptic and carcass characteristics of beef. Arkansas Agr. Exp. Sta. Bull. 697.

Linke, H., O. Fleischmann, W. Woltersdorf and F. Wirth. 1967. Der Bindegewebsgehalt in Schlachttierkorpen von Schwein and Rind. III. Mitteilung: Zum Begrill "Fleisch wie gewachsen." Fleischwirtschaft 47:744.

Lundstrom, K., K. -E. Hansson, S. Fjelkner-Modig and J. Persson. 1980. Skatole-Another contributor of boar taint. 26th European Meet. of Meat Res. Workers, $F-13$ (Abstr.).

Malmfors, B. and O. Andresen. 1975. Relationships between boar taint intensity and concentrations of $5 \alpha$-androst-16-ene-3-one in boar peripheral plasma and backfat. Acta Agr. Scand. 25:92.

Malmfors, B., I. Hansson and K. Lundstrom. 1978. Interrelationships between boar taint, $5 \alpha$-androstenone and fatty acid composition in pigs. Swedish J. Agr. Res. 8:161.

Martin, A. H. 1969. The problem of sex taint in pork in relation to the growth and carcass characteristics of boars and barrows: A review. Can. J. Anim. Sci. 49:1.

Martin, A. H, H. T. Fredeen and J. G. Stothart. 1968. Taste panel evaluation of sex effects on the quality of cooked pork. Can. J. Anim. Sci. 48:171.

Martin, T, G., T. W. Perry, W. M. Beeson and M. T. Mohler. 1978. Protein levels for bulls: Comparison of three continuous dietary levels on growth and carcass traits. J. Anim. Sci. 47:29.

McClaughterty, F. S., R. C. Cartor and J. A. Gaines. 1959. Effects of docking and castration on growth and quality of spring lambs. J. Anim. Sci. 18:1159.

McKeith, F. K., G. C. Smith, J. W. Savell, T. R Dutson, Z. L. Carpenter and D. R. Hammons, 1981. Effects of certain electrical stimulation parameters on the quality and palatability of beef. J. Food Sci. $46: 13$. 
Menzies, J. W. 1965. Physical factors affecting feedlot production of market lambs. Texas Agr. Exp. Sta, Prog. Rep. 2334.

Misock, J. P., D. R. Campion, R. A. Field and M. L. Riley, 1976. Palatability of heavy ram lambs. J. Anim. Sci. 42:1440,

Nichols, J. R., J. H. Ziegler, J. M. White, E. M. Kesler and J. L. Watkins. 1964. Production and carcass characteristics of Holstein-Friesian bulls and steers slaughtered at 800 or 1,000 pounds. J. Dairy Sci. 47:179.

Ntunde, B. N., W. R. Usborne and G. C. Ashton. 1977. Responses in meat characteristics of HolsteinFriesian males to castration and diet. Can. J. Anim. Sci. 57:449.

Orskov, E. R., C. Fraswer and I. McHattie. 1974. Cereal processing and food utilization of sheep. 2. A note on the effect of feeding unprocessed barley, maize, oats and wheat on food utilization by early-weaned lambs. Anim. Prod., 18:85.

Palsson, H. 1955. In: J. Hammond (Ed.) Progress in the Physiology. Farm Animals, 2, 430. London, Butterworths.

Patterson, R.L.S. 1968. 5 $\alpha$-androst-16-ene-3-one: Compound responsible for taint in boar fat. J. Sci. Food Agr. 19:31.

Pattie, W. A., A. C. Godlee and P. E. Bouton. 1964. The effect of castration and the poll gene on prime lamb production. Australian J. Exp. Agr. Anim. Husb. 4:386.

Paul, P. C., J. Torten and G. M. Spurlock. 1964. Eating quality of lamb. I. Effect of age. Food Technol. 18:1779.

Pelczynska, E. 1970. Wplyw zawartosci tkanki lacznej, wieku, plci i klasy jakosciowej tusz bydla rzeznego na Kruchosc miesa. Pol. Arch. Wet. 13:311.

Plimpton, R. F., Jr., H. W. Ockerman, H. S. Teague, A. P. Grifo, Jr. and V. R. Cahill. 1971. Influence of the time following diethylstilbestrol implantation on the palatability, composition and quality of boar pork. J. Anim. Sci. 32:51.

Prelog, V. and L. Ruzicka. 1944. Untersuchungen uber Organextrakte Uber zwei moschusartig riechende Steroide aus Sweinen testes-Extrakten. Helv. Chim. Acta 27:61.

Prescott, J.H.D. and G. E. Lamming. 1964. The effects of castration on meat production in cattle, sheep and pigs. J. Agr. Sci. (Camb.) 63:341.

Price, M. A. and T. Tennesson. 1981. Preslaughter management and dark-cutting in the carcass of young bulls. Can. J. Anim. Sci. 61:205.

Purchas, R. W. 1978. Some effects of nutrition and castration on meat production from male Suffolk cross (Border Leicester-Romney cross) lambs. New Zealand J. Agr. Res. 21:367.

Purchas, R. W., L. E. O'Brien and C. M. Pendleton. 1979. Some effect of nutrition and castration on meat production from male Suffolk cross (BorderLeicester-Romney cross) lambs. New Zealand J. Agr. Res. 22:375.

Ray, E. E. and R. W. Mandigo. 1963. Factors affecting retail value of lamb carcasses. New Mexico Agr. Exp. Sta. Res. Rep. 86.

Reagan, J. O., Z. L. Carpenter, G. C. Smith and G. T. King. 1971. Comparison of palatability traits of beef produced by young bulls and steers. J. Anim. Sci. 32:641.
Rhodes, D. N. 1969. The quality of meat from male and non-male animals. In: D. N. Rhodes (Ed.) Meat Production from Entire Male Animals. Pp 189-198. J and $A$ Churchill Ltd., London.

Richey, S. J. and C. Cover. 1962. Determination of collagen in raw and cooked beef from 2 muscles by alkali-insoluble, autoclave-soluble nitrogen and by hydroxyproline content. J. Agr. Food Chem. 10:40.

Riley, R. R., J. W. Saveli, G. C. Smith and Maurice Shelton. 1981. Improving appearance and palatability of meat from ram lambs by electrical stimulation. J. Anim. Sci. 52:522.

Saat, Y. A., D. B. Gower, R. A. Harrison and R. B. Heap. 1972. Studies on the biosynthesis in vivo and secretion of 16-unsaturated $C_{1}$, steroids in the boar. Biochern. J. 129:657.

Savell, J. W. 1979. Update: Industry acceptance of electrical stimulation. Proc. Recip. Meat Conf. $32: 113$

Savell, J. W., T. R. Dutson, G. C. Smith and Z. L. Carpenter. 1978a. Structural changes in electrically stimulated beef muscle. J. Food Sci. 43: 1606.

Savell, J. W., G. C. Smith and Z. L. Carpenter. 1978b. Effect of electrical stimulation on quality and palatability of lightweight beef carcasses. $J$. Anim. Sci. 46:1221.

Savell, J. W., G. C. Smith and Z. L. Carpenter. $1978 \mathrm{c}$. Beef quality and palatability as affected by electrical stimulation and cooler aging. J. Food Sci. $43: 1666$.

Savell, J. W., G. C. Smith, Z. L. Carpenter and F. C. Parrish, Jr. 1979. Influence of electrical stimulation on certain characteristics of heavy-weight beef carcasses. J. Food Sci. 44:911.

Savell, J. W., G. C. Smith, T. R. Dutson, Z. L. Carpenter and D. A. Suter. 1977. Effect of electrical stimulation on palatability of beef, lamb and goat meat. J. Food Sci. 42:702.

Schanbacher, B. D. and J. D. Crouse. 1980. Growth and performance of growing finishing lambs exposed to long versus short photoperiods. J. Anim. Sci, 51:943.

Schanbacher, B. D., J. D. Crouse and C. L. Ferrell. 1980. Testosterone influences on growth, performance, carcass characteristics and composition of young market lambs. J. Anim. Sci. $51: 685$

Schanbacher, B. D. and J. J. Ford. 1976. Luteinizing hormone, testosterone, growth and carcass responses to sexual alteration in the ram. J. Anim. Sci. 43:638.

Shelly, J. M., J. D. Kemp, W. Deweese, D. D. Kratzer and D. G. Ely. 1970. Effect of castration, slaughter weight and testosterone on lamb carcass composition. J. Anim. Sci. 31:189.

Shelton, M. and Z. L. Carpenter. 1972. Influence of sex, stilbestrol treatment and slaughter weight on performance and carcass traits of slaughter lambs. J. Anim. Sci. 34:203.

Siers, D. G. 1975. Live and carcass traits in individually fed Yorkshire boars, barrows and gilts. J. Anim. Sci. 41:522.

Sink, J. D. 1967. Theoretical aspects of sex odor in swine. J. Theor. Biol. 17:174.

Smith, G. C. and Z. L. Carpenter. 1970. Lamb carcass 
quality. 3. Chemical, physical and histological measurements. J. Anim. Sci. 31:697.

Smith, G. C., Z. L. Carpenter, G. T. King and K. E. Hoke. 1970. Chemical, physical and histological indices of lamb carcass quality. J. Anim. Sci. 31:190 (Abstr.).

Smith, G. C., T. R. Dutson, R. H. Hostetler and Z. L. Carpenter. 1976. Fatness, rate of chilling and tenderness of lamb. J. Food Sci. 41:748.

Tarrant, P. V. 1980. A survey among research establishments on the occurrence, causes and economic consequences of dark cutting beef. Presented at ECC Seminar on "The Problem of Dark Cutting in Beef," CEC, Brussels, October 7-8.

Teague, H. S., R. F. Plimpton, Jr., V. R. Cahill, A. P. Grifo, Jr. and L. E. Kunkle. 1964. Influence of diethylstilbestrol implantation on growth and carcass characteristics of boars. J. Anim. Sci. $23: 332$.

Tichenor, D. A. 1969. Effects of rate of gain, slaughter weight and castration on selected chemical, histological and organoleptic characteristics of ovine muscle and adipose tissue, Ph.D. Dissertation. Univ. of Kentucky.

Turton, J. D. 1969. The effect of castration on meat production from cattle, sheep and pigs. In: D. N. Rhodes (Ed.) Meat Production from Entire Male Animals. J and A Churchill Ltd., London.

Tylecek, J. 1958. Učelnost kastrace býčkủ pri pastevnim vykrmu mladeho skotu [The advantage of castrating bulls in fattening young stock at pasturel. Anim. Breed. Abstr. 28:542.

Walker, D. E. 1950. The influence of sex upon carcass quality of New Zealand fat lambs. New Zealand J. Sci. Technol. 32:30.

Walstra, P. and D. Kroeske. 1968. The effect of castration on meat production in male pigs. World Rev. of Anim. Prod. 4:59.

Watson, M. J. 1969. The effects of castration on the growth and meat quality of grazing cattle. Australian J. Exp. Agr. Anim. Husb. 9:164. Weninger, J. H. and D. Steinhauf. 1968. Meat quality in respect to carcass evaluation in cattle. World Rev. of Anim. Prod. 4:87.

Wierbicki, E., V. R. Cahill, L. E. Kunkle, E. W. Klosterman and F. E. Deatherage. 1955. Meat Quality. Effects of castration on biochemistry and quality of beef. J. Agr. Food Chem. 3:244.

Wilson, G. D., R. W. Bray and P. H. Phillips. 1954. The effect of age and grade on the collagen and elastin content of beef and veal. J. Anim. Sci. 13:826.

Wilson, L. L., H. Varela-Alvarez, M. C. Rugh and M. L. Borges. 1972. Growth and carcass characteristics of rams, cryptorchids, wethers and ewes subcutaneously implanted with zeranol. J. Anim. Sci. 34:336.

Wilson, L. L., J. H. Ziegler, M. C. Rugh, J. L. Watkins, T. L. Merritt, M. J. Simpson and F. L. Kreuzberger. 1970. Comparison of live, slaughter and carcass characteristics of rams, induced cryptorchids and wethers. J. Anim. Sci. 31:455.

Wipf, V. K., J. W. Carpenter, H. L. Chapman, Jr., A. Z. Palmer and T. J. Cunha. 1964. Effects of slaughter age and diethylstilbestrol treated bulls and steers. Food Technol. 10:80.

Wismer-Pedersen, J. 1968. Boars as meat producers. World Rev. of Anim. Prod. 4:101.

Wismer-Pedersen, J., P. Jonsson, P. Jensen and A. Banyai. 1969. The occurrence of sex odor in Danish Landrace boars. In: D. N. Rhodes (Ed.) Meat Production from Entire Male Animals. PP 285-296. J and A Churchill Ltd., London.

Woodhams, P. R., A. H. Kirton and K, E. Jury. 1966. Palatability characteristics of crossbred lambs as related to individual Southdown sires, slaughter age and carcass fatness. New Zealand J. Agr. Res. $18: 261$.

Wong, E., C. B. Johnson and L. N. Nixon. 1975. Mutton odor. Chem. Ind $4: 40$.

Zinn, D. W., L. A. Holland and P. E. Neale. 1963. Effect of breed and sex on live animal and carcass measurements in lambs. J. Anim. Sci. 22:829. (Abstr.). 